\title{
Sustainable tourism at mass tourist destinations: best practice from tourist producers in Europe
}

\author{
A. Sörensson \\ Mid Sweden University, Sweden and Åbo Akademi University, Finland
}

\begin{abstract}
Within the tourism industry, a large focus has been made towards sustainable tourism since the 1990s. Sustainable tourism focuses on tourism from an economical, social and environmental aspect. There is a big consensus among politicians, tourist producers and researchers that the tourism industry should be sustainable. However, the question is how can this be reached? Previous research has not yet focused on the tourist producers' perspective on sustainable tourism at different mass tourist destinations. The aim with this study was to examine how different tourist producers at different mass tourist destinations work with sustainable tourism as a strategic marketing tool in their tourism product development. The study was conducted with a qualitative approach using case studies. The data was collected during 2006-2009 from interviews with tourist producers and observations at the destinations. Four destinations were selected as cases in Europe: Rimini in Italy, Lloret de Mar and Granada in Spain and Gotland in Sweden. There was also a mix of different tourist producers at the destinations: hotels, restaurants, attractions and experiences. The result indicates that the destinations' conditions have an impact on the tourist producers' reasons for working with sustainable tourism. Sustainable tourism is used by the tourist producers as a strategic marketing tool but in different ways depending on the destination. There is a variation among the tourist producers between the destinations and they focus mainly on one of the three aspects within sustainable tourism. The result indicates that the different producers have different strategic agendas when working with sustainable tourism.
\end{abstract}

Keywords: sustainable tourism, marketing, case study, mass tourism, tourist producer, tourism product development. 


\section{Introduction}

Tourism is one of the fastest growing sectors in Europe and has been a prioritised area for the European commission since the mid-1990s. The tourism sector is Europe's largest industry, with over $60 \%$ of all tourism in the world, and it is expected to grow even more. Resources within tourism are limited due to natural, economic, social and cultural aspects and will not survive continued growth. Demands are being made by the European Union that the necessary steps are to be taken in order to achieve successful sustainable tourism. The goal in Europe is to guarantee economically, socially and environmentally sustainable tourism [1]. There is a consensus that tourism development should be sustainable, but the question is how? [2, 3]. The concept of sustainable tourism has its starting point in the Brundtland Commission Report, which defined sustainable development [4]. It is all about finding a balance between economical, social and environmental issues. But can a balance between these three values really be reached? The definition of "sustainable development" contains a contradiction. It has a focus on preservation but also on development, which implies a society where economic growth leads to greater wellbeing. Harris and Leiper [5] define sustainable as "not using non-renewable resources faster than renewable substitutes can be found for them". Sustainable development has been interpreted in a spectrum from very weak to very strong sustainability position. In the same way, sustainable tourism is still discussed and evolving $[6,7]$. Those with a very strong approach argue that sustainability can only be reach if focus is on no use of the natural resources meanwhile those with a very weak approach argue that economic growth is a must by using technical innovations as well as natural resources. These different interpretations exist not only among researchers both also frequently in governmental policy documents $[8,9]$. Swarbrooke [10] believes that sustainable tourism is maximizing the economical, social and environmental benefits, while at the same time suggesting that sustainable tourism involves a maximization of the economical, social and environmental benefits of tourism with a simultaneous minimization of cost. Middleton and Clarke [11] state that the new economy has to find a balance between these three dimensions. Economic interests should be balanced against the environment. Companies should maximize their profits, but also take an environmental responsibility. Companies prefer to mass produce with a focus on the economy and low costs, but the tourist prefers quality and also wants to enjoy a destination's social life through its culture. But how can tourist producers find a balance within these three factors? Previous research has not yet focused on the tourist producers' perspective on sustainable tourism at different mass tourist destinations.

At a tourist destination the tourist are buying different services and the importance of service quality is well established within the business context, both among researchers as well as among organizations like tourist producers $[12,13]$. Therefore, for the service industry tourism is an essential part [14]. Tourism, as an industry, differs from ordinary industry in mainly three ways. Firstly, the tourist must be imported to the production site (the destination). 
Secondly, the tourist is a co-producer and an active part in the production, delivery and consumption. Thirdly, the destination involves many co-operative collective bodies but still there is individual business competition [15].

With the emerging interest for service marketing, the concept service quality became interesting to study in the 1980s [16]. Services are defined by the four main characteristics; intangibility, inseparability, heterogeneity and perishability [17]. These four characteristics are now being questioned since the emergence of a new marketing paradigm, the service-dominate logic (S-D logic), which argues services more as a process where value is created [18-20]. Further on, S-D logic shows that marketing become more a management strategy that includes all part of the organization instead of just a marketing department. S-D logic argues that all types of organizations are selling services. A hotel is not selling a hotel night but instead sleep, the same way as selling a drilling machine means selling holes in the wall $[21,18]$. For the tourist producers it can therefore be strategic to focus its marketing on sustainability as a part of the value the tourist are buying. It will not be sustainability that is the core value but instead an indirect value connected to the service. This new paradigm, the S-D logic, can therefore create a new focus for tourist producers that work with sustainable tourism. The aim with this study is to examine how various tourist producers at different mass tourist destinations work with sustainable tourism as a strategic marketing tool.

\section{The concept of sustainable tourism}

Since tourism is a rapidly growing industry it is important to create more sustainable tourism in order to make the tourist return to the destination. There are many dimensions to a destination, such as economical, social, cultural, political, geographical and environmental aspects. This makes it hard to limit the question of sustainability in to a certain research field [22]. Additionally, Hall and Lew [23] discuss how defining sustainable development is difficult since it is problematic incorporating all these three fields into one definition. How can we achieve sustainable development when we refer to sustainability in tourism in the opposite way, preservation instead of development?

Clarke [6] has shown that the concept has gone through several paradigm shifts. At the starting point there was a difference between tourist producers that was working with mass tourism and the opposite which instead worked with sustainable tourism. The second step was to see mass tourism as a continuum where mass tourism was one side and on the other side there was sustainable tourism. Both this paradigm did not really show the reality of tourism. Tourism is instead a far more complex and dynamic industry since there are several tourist producers at a destination. Another issue is also that sustainable tourism often is small scale and mass tourism is not, instead there are a huge number of tourists coming to the destination. The latest paradigm is arguing upon sustainable tourism as a goal for all tourism, despite its size [6].

Tourists' behaviours depend on price, quality and the image of the destination and also on the tourist's individual interests. In tourism production many actors create the entire "product". The marketing of destinations therefore depends on 
these actors' different values [24]. Von Friedrichs Grängsjö [25] claims that destination marketing differs from the traditional marketing. Instead there must be a focus on networking, where the firms are part of the destination's surroundings. Coase [26] discusses is that when many actors are involved in tourism, it often results in the firms wanting to raise their profits without thinking about the environment. There is often a lack of responsibility for the shared environment. For small businesses it seems to be easier to set up sustainable commitments. This might be due to good communication and coordination within the firm [27].

\section{The service-dominant logic}

Vargo and Lusch [18] argues that there has been a paradigm shift within the marketing field where the term "service" has gotten a new meaning. In the traditional service marketing there has been a difference between products and services. Vargo and Lusch [18] define service as "the application of specialized competences". Due to the new paradigm, the service-dominant logic (S-D logic), a larger focus has established on service delivery to the tourist. "It is important to note that $S-D$ logic uses the singular term, "service", which reflects the process of doing something beneficial for and in conjunction with some entity, rather than units of output - immaterial goods - as implied by the plural "services" [28]. In this sense all employees become service delivers of the value to the customer [29]. Vargo and Lusch [18, 19, 28, 30] argue that all offers are services which means that the entire management must be included in the work. For a destination this means that all tourist producers become a part of the final value for the tourist. The tourist travels to the destination for a particular reason that can differ for various tourist segments. At a destination the tourist wants to stay at an accommodation, dine at restaurants and experience activities [31]. There are several parts that together give the tourist his or her experience but it is the final value that is of interest. The S-D logic argues that there are several steps in the supply chain but it is the final value for the tourist that is central. When travelling to a destination it is the total experience that is the final value, despite that it can be several tourist producers involved in the supply chain. Therefore is the image of the destination central [18, 32].

For the hotel or a restaurant it is important not to have only a marketing department, but instead see the entire organization as service providers to the tourists. Gummesson [33] discuss that all employees are marketers; on full time or part time and therefore is the entire firm marketers. When value is created the guest must be part of the process as co-creator. Value is depending on the guest since the value is created during consumption. Hotels and restaurants at a destination are dependent on its surrounding environment, because that is the main reason for the tourist to come there. They need to preserve it in order to exist in the long run [34]. The hotel can therefore not deliver value, but only offer value propositions. For the hotel to get more information about their guest they need to create relations. Only by knowledge about the guest needs can the management offer value to meet the guests' expectations. Many guests have the 
experience of getting an individual value offer that meets the exact needs. Guests have different needs which are depending on their subjective service quality needs. The hotel therefore need, more than ever, to create methods for continuing knowledge about the expectations and needs of the guests [18, 32].

\section{The research process}

The study was conducted with a qualitative approach using multiple case studies. The data was collected during 2006-2009 from interviews with different tourist producers, and observations at the destinations [35, 36]. The study was performed under several years and the whole research process was done with an abductive research process [37]. Halinen and Törnroos [38] list several steps in a research process which was followed in this study. The first step was carried out through observation at tourism producers, where the tourist producers presented their firm's work with sustainable tourism. The second step was that qualitative interviews were carried out with the tourist producers, in some cases up to one year after the first observations. At some of the destination another observation was performed as a third step. Four destinations were selected as cases in Europe; Rimini in Italy, Lloret de Mar and Granada in Spain and Gotland in Sweden. There was also a mix of different tourist producers at every destination; hotels, restaurants and activities. At each destination three tourist producers were interviewed using a semi-structured questionnaire. At each destination a local actor from the municipality helped by naming the best examples of sustainable tourism at their destination.

The results were based on the empirical data from both interviews and observations. The data was analyzed and interpreted, resulting in categories structured from the three dimensions of sustainable tourism. Lincoln and Guba $[39,40]$ discuss trustworthiness as a way to judge the quality in qualitative research. Since there was only a few tourist producers at each destination that was interviewed, the result cannot be generalized for all tourist producers at each destination. There is however a first step in theory generation that should be followed by comparison to other cases of sustainable tourism at mass tourist destinations $[41,38]$. This also leads to that the results are tested and a complete theory can emerge.

\section{The case of sustainable tourism at European mass tourist destinations}

All four destinations are mass tourist destinations. In Rimini, the majority of tourists are domestic, but there are also international tourists primarily from June until August. The entire season is from Easter until October for most of the tourist producers in Rimini. From May until September, Rimini has 1.9 million tourists and over 12.7 million overnight stays [42]. However, in recent years there has been a decline in tourism in Rimini. The peak was during the 19701980s and since then fewer tourists have chosen to spend their holidays in Rimini. 
In Lloret de Mar the main category is budget tourists, and the majority arrive during July and August. There are about 38,000 inhabitants in Lloret de Mar and during the summer season the destination often has over 200,000 people, including the local inhabitants, in the city. Most of the tourists are international guests, mainly from the United Kingdom, France and Germany, who come for the beach and the sun. There are also domestic guests that come to Lloret de Mar, often for weekends or they may own a second home there.

In Granada, most of the tourists are international; mainly due to the main attraction "Alhambra" which is one of Europe's most famous attractions in Europe, an old palace built by the Moors. More than two million tourists come to visit the monument every year. Many of the tourists come during the day and do not spend the night in Granada. They come by bus in the morning and leave in the afternoon. One problem for Granada is thus that tourists come to the coast during the summer and to the mountains in the winter, but not many choose to stay in Granada.

Gotland is one of the most popular summer destinations and is also the biggest island in Sweden with tourism and agriculture as its two main industries. The last ten years has the tourism industry grown and attracts now about 800,000 tourists per year. The tourists come mainly during the summer season from Sweden and also from Germany [43]. Except for these tourists there is a large segment of tourist that has their second home at Gotland [44].

\section{Tourist producers developing sustainable tourism}

Different tourist producers work in different ways to create sustainable tourism at the different destinations. They focus on the three factors - economical, social and environmental - but are creative in different ways, for different reasons.

In Rimini tourist producers are focusing on working harder with environmental questions. Italia in Miniatura has received the ISO14001 standard and has also created a specific attraction, like an eco-house, within the park that focuses on environmental issues for children. This is the only theme park with an environmental label in Europe. They say that they are trying to think about environmental issues as a chain in the entire firm. Italia in Miniatura wants to be a serious company with a strong brand, but with responsibility. "Hotel Sport" has also started changing environmental issues at the hotel, especially by focusing on bikers. The tourist producer that runs the "Bano" has also worked with the environmental issues. He says that it is an ethical responsibility. The beach has reduced their water consumption by $70-80 \%$. At the beach they also have an info point that informs the tourists about the water and air quality every day. Another change is that the path down to the sea is not longer made from concrete but from olive stone and foam, which are recycled from olive production in the area.

In Lloret de Mar the focus is mainly on economic interests. "Hotel Samba" was the first hotel in Spain to get the eco-labels ISO14001 and EMAs, and is also the first hotel in Europe to have both. These labels have given the hotel a lot of publicity and reports in different magazines and TV programs. The hotel manager thinks that Lloret de Mar has been and still is a low cost destination that 
offers sunshine and beaches. Recently they have tried to change the mentality at the destination. He says that they have to believe in what they are offering to the tourist, and not just focus on low prices. The hotel has changed their water, energy and garbage systems. The investment cost is high, but in two years the investment has paid off due to a significant reduction in water and energy consumption. The main reason for this is that the hotel saves money and makes a higher profit. The environmental issue is not the reason behind. The bike company started their business since because there was no bike rental firm in Lloret de Mar. According to the owners their business idea is sustainable, since they are hopefully getting tourists to use bikes instead of cars or buses, but the main reason is to have a company they can live on. Therefore, the economy is the main reason for these tourist producers as well.

The tourist producers in Granada focus mainly on the social aspect of sustainable tourism. According to the owners of the firms there is no major focus on environmental questions, but instead more on cultural and social aspects. The bike firm "Otros Caminos" focuses on the culture in the area, letting the tourist bike from one village to another. The routes that they bike on are old and have a specific cultural heritage. The reason is to allow the tourists to "taste the history", according to the owner. The hotel "Casasola" was originally a family home that the owners have renovated and turned into a small hotel. The feeling of the hotel should be like being at home. Most of their tourists come for biking and hiking, and they learn more about Granada's history, nature and gastronomy. The food that the hotel serves the tourists is mainly locally produced $(90 \%)$. The owner said that they are presenting rural tourism, which also means that the tourists do not just come during the busy summer months but all year round. The ecological restaurant "El Molino" specializes in the revitalization of regional gastronomy. The restaurant has been renovated after being a ruin when the owner started. The aim is to serve locally produced food in the restaurant and also use traditional recipes from the region.

The tourist producers in Gotland focus most on the environmental aspect of sustainable tourism. The hotel "Furillen" has from the starting point focused mainly on the environment. The hotel is a former fabric that was rebuilt into a hotel, focusing on exclusive design based on mainly local produced furniture with a strong cultural aspect to Gotland. Furillen is one of the most famous hotels in Europe and attracts a large number of photographers for fashion magazines in the world. The hotel offers a surrounding that is well suited for photoshoots. The entire hotel has an environmental focus and also with strong cultural focus. The restaurant at the hotel also serves mainly local, environmental friendly food. The owner has plans to charge the hotel guest extra if the use the heaters, instead of using the fire place in their rooms by themselves. The other restaurant, Creperiet, situated in the central parts of the major city Visby, serves lunch and dinner with a focus on environmental friendly food as well. They started the company with the idea of living on Gotland and enjoying life. The social aspect also has a big focus for the manager of the restaurant and also here design is in focus in the restaurant. The fishing company, Fish your dreams, has an environment focus on the company. He offers exclusive fishing trips around 
the island. The entire trip should be an experience that offers accommodation and dining as well as the fish experience.

\section{Discussion}

The destinations are at different stages of the product lifecycle. Granada, Lloret de Mar and Gotland are at the maturity stage, while Rimini is at the decline stage. There is also a difference in their types of tourists; Rimini and Gotland has mainly domestic tourists, compared to Granada and Lloret de Mar that have more international tourists. There are also differences in what the destinations have to offer tourists. Rimini and Lloret de Mar mainly have beaches and sun, while Granada has its history and traditions, mainly "Alhambra". Gotland main attraction is the sun and beach, but there is also a culture inheritage that attracts some tourist segments. The strategic sustainability issues also differ for the destinations. Rimini has a focus on improving the quality of the seawater, while both Spanish destinations want to earn more money from the tourists. In Lloret de Mar they have mass tourists who come for cheap holidays. In Granada the tourists come for the day and therefore do not spend money on hotels and restaurants. Gotland has the problem of attracting tourists mainly during two months of the year. The results are shown in the table below.

Table 1: $\quad$ Strategic destination issues.

\begin{tabular}{|c|c|c|c|c|}
\hline Destination & Lifecycle & Tourism & $\begin{array}{c}\text { Main } \\
\text { attraction }\end{array}$ & $\begin{array}{l}\text { Strategic } \\
\text { issue }\end{array}$ \\
\hline Rimini & Decline & $\begin{array}{c}\text { Domestic } \\
\text { April-October }\end{array}$ & $\begin{array}{l}\text { Sun and } \\
\text { Beach }\end{array}$ & $\begin{array}{l}\text { Quality of } \\
\text { the seawater }\end{array}$ \\
\hline $\begin{array}{l}\text { Lloret de } \\
\text { Mar }\end{array}$ & Maturity & $\begin{array}{c}\text { International } \\
\text { May-September }\end{array}$ & $\begin{array}{c}\text { Sun and } \\
\text { Beach, Sport }\end{array}$ & $\begin{array}{c}\text { Low budget } \\
\text { strategy }\end{array}$ \\
\hline Granada & Maturity & $\begin{array}{c}\text { International } \\
\text { All year }\end{array}$ & $\begin{array}{l}\text { History and } \\
\text { Culture }\end{array}$ & Day tourism \\
\hline Gotland & Maturity & $\begin{array}{c}\text { Domestic } \\
\text { June-August }\end{array}$ & $\begin{array}{l}\text { Sun and } \\
\text { Beach, } \\
\text { Culture }\end{array}$ & Short season \\
\hline
\end{tabular}

There are differences in how the tourist producers prioritize in their marketing of sustainable tourism at mass tourism destinations as illustrated in the table below.

Table 2: $\quad$ Marketing focus of sustainable tourism.

\begin{tabular}{cccc}
\hline Destination & Primary focus & Secondary focus & Third focus \\
\hline Rimini & Environment & Economy & Social \\
Lloret de Mar & Economy & Social & Environment \\
Granada & Social & Environment & Economy \\
Gotland & Environment & Social & Economy \\
\hline
\end{tabular}


In Rimini they primarily focus on environmental issues. They want to create more sustainable tourism and are doing so by working harder with the environment. By changing tourism and making it more environmentally friendly, they are earning more money. For instance "Italia in Miniatura" can use their children's environment room to attract more schools and thus have a longer season than before. If this is seen as a chain, we can see that starting working with the environment leads to earning more money and therefore causing social effects. One example of social effects could be that the inhabitants can work almost all year and not just during the summer months.

Compared to Rimini, Lloret de Mar's tourist producers are focused on earning money using a low cost strategy. They are not yet working with environmental issues to the same extent. At "Hotel Samba", the efforts to reduce consumption is done mainly in order to lower costs for water and electricity. If they earn money, this will have social effects and then they might have time to focus on environmental issues. In Granada the social and cultural roots are the focus of all the tourist producers. They are trying to display their history and tradition in the tourist products they offer. By using their history, they attract tourists and therefore earn money, so in the end they might have time to work with the environment. The tourist producers at Gotland focus on environment but also with a clear social and cultural focus.

\section{Conclusions}

The destinations have different problems at their destination and what they need to develop. Rimini as a destination is in decline and needs to improve quality in order to attract tourists because their brand is tired. Lloret de Mar needs to focus on more than earning money in order to keep the tourists, since they just offer mainly sunshine and beach. Sunshine and beach is not unique and tourists can easily choose other destinations around the Mediterranean Sea. Granada needs to focus on trying to get the tourists to stay, because they have many that visit Alhambra but too few that spend their holidays there. Gotland has a short season and needs to attract tourist during more times than in the summer. Each destination has a strategic issue that the tourist producers are working with in order to creating a more sustainable tourism. The result indicates that the tourist producers have focused their own tourism product development against the strategic issue at the destination.

The conclusion is that tourist producers primarily focus on one aspect of the concept of sustainable tourism. By focusing on one aspect within sustainable tourism, it will also have consequences on the other two aspects. In Rimini they focus on the environment since seawater quality has been a problem. In Lloret de Mar the economical factor is most important and environmental issues are covered in order to earn more money. In Granada their Alhambra heritage and its history is the destination's focus. The tourist producers at Gotland are trying to work with environment by using local products. As a first indication we therefore must be aware that the concept sustainable tourism means different focus for different tourist producers. The concept has a contradiction and this 
multiple case study has indicated that tourist producers work differently with sustainable tourism, with mainly one focus.

The result also indicates that the destination conditions have an impact on the tourist producers' reasons for working with sustainable tourism. Sustainable tourism is used by the tourist producers as a strategic marketing tool but in different ways depending on the destination. There is a difference among the tourist producers between the destinations and they focus mainly on one of the three aspects within sustainable tourism. The result indicates that the different producers have different strategic agendas when working with sustainable tourism. Some of the tourist producers have a clearer connection between their tourism products developments compared to others. One destination is one experience for the tourist and therefore need to have a common approach in order to keep the destination together. The new marketing paradigm can be useful for further studies in sustainable tourism and marketing since it clearly shows the importance to see every little bit as one part of the final value for the tourist. It is no longer a difference between many services; instead the tourist producers must work with sustainable tourism as a part of the final value that the tourist is buying. The tourist is buying a final value, and is also a co-creator which means that we need to know more about the tourists' thoughts about sustainable tourism. A suggestion for further research is therefore to focus on the mass tourists and their expectations on sustainable tourism.

\section{References}

[1] European Commission, KOM (2003)716 final.

[2] Bramwell, B. \& Lane, B., Sustainable tourism: an evolving global approach. Journal of Sustainable Tourism, 1(1), pp. 1-5, 1993.

[3] Gössling, S. Peeters, P. Ceron, J-P. Dubois, G. Patterson, T. \& Richardson, R.B. The Eco-efficiency of tourism. Ecological Economics, 54 (4), pp. 417434, 2005.

[4] Report of the World Commission on Environment and Development: Our Common Future (WCED), 1987.

[5] Harris, R. \& Leiper, N. (1995). Sustainable tourism - an Australian perspective. Oxford: Butterworth-Heinemann. p. xix.

[6] Clarke, J. A Framework of Approaches to Sustainable Tourism. Journal of Sustainable tourism. 5(3), pp. 224-233, 1997.

[7] Liu, Z., Sustainable Tourism Development: A Critique, Journal of Sustainable Tourism, 11(6), pp. 459-475, 2003.

[8] Hunter, C. Sustainable Tourism as an Adaptive Paradigm, Annals of Tourism Research, Vol 24, No 4, 99 850-867, 1997.

[9] Turner, R. K. Pearce, D, \& Bateman, I. (1994). Environmental Economics: An Elementary Introduction. Hemel Hempstead: Harvester Wheatsheaf.

[10] Swarbrooke, J. (2002). I: Buhalis, D. Laws, E. (ed). Tourism distribution channels - practice, issues and transformations.

[11] Middleton, V. Clarke, J. (2001). Marketing in travel and tourism. Oxford: Butterworth-Heinemann. 
[12] Wilkins, H. Merrilees, B. Herington, C., Towards an understanding of total service quality in hotels, International Journal of Hospitality Management, 26(4), pp. 840-853, 2007.

[13] Grönroos, C. (2007). In Search of a New Logic for Marketing Foundations of Contemporary Theory. West Sussex: John Wiley \& Sons, Ltd.

[14] Otto, J. \& Ritchie, B., The service experience in tourism, Tourism Management, 17(3), pp 165-174, 1996.

[15] Von Friedrichs Grängsjö, Y. \& Gummesson, E., Hotel Networks and Social Capital in Destination Marketing, International Journal of Service Industry Management, 17(1), pp. 58-75, 2006.

[16] Grönroos, C. (2000). Service Management and Marketing - a customer relationship management approach. West Sussex: Wiley.

[17] Parasuraman, A. Zeithaml, V.A. Berry, L.L., A Conceptual Model of Service Quality and Its Implications for Future Research. The Journal of Marketing, 49(4), pp. 41-50, 1985.

[18] Vargo, S. L. Lusch, R. F., Evolving to a New Dominant Logic for Marketing, The journal of Marketing, 68(1), pp. 1-17. 2004a.

[19] Vargo, S. L. Lusch, R. F., The Four Service Marketing Myths - Remnants of a Goods-Baset, Journal of Service Research, 6(4), pp. 324-335, 2004 b.

[20] Lovelock, C. Gummesson, E., Whither Service Marketing? In Search of a New Paradigm and Fresh Perspective, Journal of Service Research, 7(1), pp. 20-41, 2004.

[21] Levitt, T. (1960). Marketing myopia. Harvard Business Review. Vol. 38 (April), 3-13.

[22] Aronsson, L. (1997). Turismens hållbara utveckling? Karlstad: Forskargruppen Turism och Fritid. p.15.

[23] Hall, M. Lew, A. (1998). Sustainable tourism - a geographical perspective. Essex: Addison Wesley Longman Limitied.

[24] Von Friedrichs Grängsjö, Y. (1999). Destinationsmarknadsföring - en studie om turism från ett producentperspektiv. Stockholm: Stockholms Universitet.

[25] Von Friedrichs Grängsjö, Y. (2003). Destinationsmarknadsföring: Företag i nätverk. I: Larson, M. (ed). Svensk turismforskning - en tvärvetenskaplig antologi om turister, turistdestinationer och turismorganisationer. Östersund: Etours vetenskapliga bokserien.

[26] Coase, R. (1992). Företaget, marknaden och lagarna. Kap. 1. Stockholm: Ratio.

[27] Cavagnaro, E. \& Gehrels, SA., Sweet and sour grapes: implementing sustainability in the hospitality industry - a case study, Journal of Culinary Science and Technology, 7(2) pp. 181-195, 2009.

[28] Vargo, S. L. Lusch, R. F., Why "service"?, Journal of the Academic Marketing Science, 36, pp. 25-38, 2008.

[29] Bjurklo, M., Edvardsson, B., Gabauer, H., The role of competence initiating the transition from products to service, Managing Service quality, 19(5), pp. 493-510, 2009. 
[30] Vargo, S. L. Lusch, R. F., Service-dominant logic: continuing the evolution, Journal of Academic Marketing Science, 36, pp. 1-10, 2007.

[31] Mossberg, L., A marketing approach to the tourist experience, Scandinavian Journal of Hospitality and Tourism, 7(1), pp. 59-74, 2007.

[32] Kristensson, P. (2009). Den tjänstedominanta logiken - innebörd and implikationer för policy. Vinnova rapport. VR 2009:07.

[33] Gummesson, E. (2002). Relationsmarknadsföring: Från 4P till $30 R$. Malmö: Liber.

[34] Bader, E.E., Sustainable hotel business practices, Journal of Retail and Leisure Property, 5(1), pp. 70-77, 2005.

[35] Yin, R. (2003). Case study research - design and methods. London: Sage Publications.

[36] Stake, R. E. (1995), The Art of Case Study Research, Sage Publications, London.

[37] Järvensivu, T. \& Törnroos, J., Case study research with moderate constructionism: Conceptualization and practical illustration. Industrial Marketing Management, 39, pp. 100-108, 2010.

[38] Halinen, A. \& Törnroos, J-Å., Using case methods in the study of contemporary business network, Journal of Business Research, 58(9), pp. 1285-1297, 2005.

[39] Lincoln, Y. S, \& Guba, E. G, (1985). Naturalistic inquiry. Newbury Park, CA: Sage.

[40] Lincoln, Y. S, \& Guba, E. G, (2000). Paradigmatic controversies, contradictions and emerging confluences. In N.K. Denzin, \&Y.S. Lincoln (Eds), Handbook of qualitative research (pp. 163-188)., $2^{\text {nd }}$ ed, London: Sage Publications.

[41] Eisenhardt, K., Building theories from case study research. Academy of management review, 14(4), pp. 532-550, 1989.

[42] Brau, R. \&Scorcu, A. E. \& Vici, L. 2007. Assessing visitor satisfaction with tourism rejuvenation policies: the case of Rimini, Italy, Working Papers 617, Dipartimento Scienze Economiche, Università di Bologna.

[43] Gotlands kommun, www.gotland.se.

[44] Bygg-Gotland - översiktsplan för Gotlands kommun 2010-2025. 